\title{
12. THE CHERUBIC HYMN IN THE ROMANIAN CHORAL CREATION
}

George Dumitriu ${ }^{121}$

\begin{abstract}
The Cherubic Hymn (gr.) o heroubikos ymnos) was introduced in the Byzantine Liturgy in the $5^{\text {th }}$ century, by a decree of Emperor Justin the $2^{\text {nd }}$, issued in 574. The document stated the replacement of an old psalm, once sang during the offering of bread and wine gifts at the altar by the church-goers (ofertorium), with the new hymn. The replacement of the ofertoriumului ritual with the one of Presentation of the Euharistic Gifts (the Great Exodus) and the introduction of associated memorials, determined the fragmentation of the hymn in two different parts. Initially sang monodically, the introduction of the art of chorale in the Orthodox Church determined the development of this liturgical singing in two parts with a different musical nature, based on the principle of contrast: Cherubic, in large tempo (Adagio) and That we may receive the King in moderate tempo (Moderato). The first induces an atmosphere of mystical chastity, leads to introversion, and the second is a glory hymn, imposing and majestic. Literary, The Cherubic consists of the following three sentences, which determined the subsequent form of homonym choral creations,
\end{abstract}

We, who mystically represent the Cherubim,/

And chant the thrice-holy hymn to the Life-giving Trinity.

Let us set aside the cares of life,

Followed by another two sentences and the threefold repetition of the ovation "Hallelujah!", which form the second hymn:

That we may receive the King of all!

Who comes invisibly escorted by the Divine Hosts!

Hallelujah, Hallelujah, Hallelujah!

In the Romanian liturgical chorale creation the Cherubic hymn bears the following stylistic directions: 1. of Slavic influence; 2. of Classical-Romantic inspiration; 3. which capitalizes the Byzantine church singing.

Key words: Cherubic Hymn, Orthodox Church, homonym choral creations

\section{Slavic-influenced Cherubics}

The first cherubics in the Romanian chorale literature were translations from the creation of Russian composers ${ }^{122}$. They constituted models to be followed for Romanian composers. The influence of Russian chorale liturgical creation on the Romanian School for church chorale composition left its mark the most clearly on the musical structure of the Cherubic hymn, together with the one of the religious concert. From the Russian perspective, the Cherubic hymn acquires a strophic structure, with its versions, from the simplest one monostrophic, in which all the three literary phrases are identically or diversely

\footnotetext{
${ }^{121}$ Associate Preofessor PhD., "George Enescu” National University of Arts from Iași, Romania, email: georgedumitriu@yahoo.com

${ }^{122}$ Dimitrie St. Bortnianski, Grigore Lvovski, Gavril Lamakin.
} 
repeated, to tristrophic barform forms. Moreover, the unitary vision of the liturgy of the Russian Church on Cherubic hymns and That we may receive the King of all, seen as two distinct parts of the same hymn (Heruvimskaia), shines through in Russian partitions, according to which the second one does not have a title, that would define it as an independent part, but comes after the first one, as a contrasting motion. The answer Amen $^{123}$ separates them, and sometimes only a double line, with the indication of a more moderate tempo. This vision was also transferred on the first Romanian cherubics, with a clear Russian inspiration.

The monostrophic Cherubic is especially found in the first Romanian chorale liturgies, created in the form of translations and of adaptations from the Russian chorale literature (Gheorge Burada, Ion Cartu-1865, George Fotino, Gavriil Musicescu, op.I-1869 and Mihail Berezovschi). The cherubics of Dimitrie Bortnianski were as models, out of which, the simplest one is the Chrubic in $\mathrm{Fa}$ major, in ternary meter. The facile and coherent melody, achieved by a gradual motion and on a flat fifth range $\left.\left(m i_{1}-s i \text { flat }\right)_{1}\right)$, unitary rhythm and airy harmony, based only on the succession of the accords of the main steps, made it accessible to amateur choirs of that age. It appears both in the Liturgy of Musicescu opus 1, as well as in the collection of liturgical hymns created by Mihail Berezovschi. The difference between the two translations is found only at the level of the adaptation of the Romanian text and of the standard metric quantity (half note, in Musicescu and quarter note in, Berezovschi). The numerical difference of the syllables at the level of each literary phrase reflects in the rhythmic organization of the quantities, within musical verses.

The monostrophic form of the Cherubic (Adagio) is also reflected on the That we may receive the King of all (Allegretto) hymn, the second one maintaining the same musical discourse, the difference being only in the tempo. Another monostrophic cherubic, with a more elaborate musical discourse, belongs to the liturgy male chorale written by Ioan $\mathrm{Cartu}^{124}$ for three equal male voices (Bass-Tenor 1 and 2). in the fa minor tonality, in the ternary meter (3/4) and with a starting point the third step of the tonality (the sound of la flat), the melody of the first phrase sketches a sinuous ascending-descending motion, made by conjunct and disjunct major third interval successions (la flat-do 2 ). Carrying out in a tempo specified through a character term (Maestoso), the melody discourse is launched into the third measure due to eigth note arpegiatto motion (la flat-do2-fa 2 ). Once the melodic ictus was reached $\left(f a_{2}\right)$, it is followed by a postcrusic moment reduced to the size of two measures, by which it returns to the initial sound.

Rhythm plays an essential role in the progressive activation of the melody: balanced by equal values (quarter notes and eigth notes) in the first

\footnotetext{
${ }^{123}$ from the memorials of the Vohod (Presentation of the Precious Gifts).

${ }^{124}$ The Liturgy of Saint John Chrysostom, arranged on three male voices [...], Bucharest, Imprimeria lui Ioan Cartu, 1865.
} 
measure, dotted in the second one, accelerates by arpegiatto eigth notes in the third measure, in order to immediately steady by bringing back the initial values (quarter notes). The second musical phrase, derived from the first one by translating the beginning to a major third note, brings clearness to the major oblique motion (measures 6-9), so that in the last phrase (measures 10-16) it shall come back to the initial tonality through a descending melismatic motion, in eigth notes (measures 11-12).

The monopartite form is also found in the cherubics of Bessarabian composer Mihai Berezovschi (no. 1, in fa\# minor and no. 2, in Do major). The thematic material of the dinic musical discourse in the second section - That we may receive the King of all - is identical to the one in the first section, only the tempo changes. The most often used structure in creating cherubics, by Romanian composers, is the one in two contrasting motions. The first part (the Cherubic) - in large tempo - contains three periods organized according to the barform model (AAB), with the following tonal relation: sections $\mathbf{A}$ are in a major tonality, and section $\mathbf{B}$ brings either the oblique motion (most of the cases), or the minor homonym motion. The structure mentioned is specific to the cherubics created by Ioan Bunescu, Alexandru Podoleanu, Ioan G. Mugur, Jean Gabrielescu, Gavriil Musicescu, Ioan Popescu-Runcu.

The cherubics created in the style of Russian ecclesiastic choirs is characterised especially through the hieratic atmosphere that it generates, inducing an emotional state of introspection, which leads to introversion. The melodies sketch small-sized contours, in which the gradual motion prevails, in equal oblique values, on an airy harmony, with authentic I-V-I-IV-I or I-V-I$\mathrm{V}$ tonal successions. Defining for the liturgical choral style of Russian influence are the two cherubics of composer from Iasi Gavriil Musicescu: in Re major, written for a mixed choir of 6 voices (derived from the division of tenors and basses) and in Do major, for a mixed choir of 8 voices. Both have a predominantly homophone writing. The specificity of these cherubics consists in the constitution of this hymn in two suite contrasting motions, connected by dominant accords, with the role of a bridge (the Amens in the memorials).

The Cherubic in Re major, opus 5, (Adagio, $\left.\mathbf{4}_{4}^{4}\right)$ is written for a mixed choir of six voices: Sopranos, Altos, Tenors I and II, Barytones, Basses. The first part has a barform structure: AA (Adagio) B (Andante in re minor) + bridge (Amen). The second part (That we may receive the King of all - Allegro, in Re major) has a tristrophic form: $\mathbf{A B C}$, in which the median stanza bring the oblique tonality (La major).

The Cherubic in Do Major (Adagio) has the form of a lied (ABA) and is written for a choir of 8 voices. Period $\mathbf{A}$ is presented by the male choir, period $\mathbf{B}$ is entrusted to the female choir, and the reprise reunites the two choirs, the musical discourse acquiring a sonorous ampleness and a timbre richness. The second part (That we may receive the King of all) has a free form and combines the homophone writing with the response polyphone writing. 
2. Classical-Romantic inspired Cherubics are characterised through their great diversity regarding the musical language elements used. Therefore, great differences emerge from one author to another. The lied form, in which these cherubics are written, constitutes the only common element. The melodies lack a thematic unity, area created freely, following tone trajectories pre-established by the composer, usually in the area of related tonalities. The tonal schemes covered are much more than in the case of Slavic-inspired chorale cherubics. For instance, Cherubic in mi minor, by Eduard Wachman, covers the following tone scheme: mi minor-Do major-mi minor-si minor-Sol major-mi minor-la minor-mi minor.

In most cases, these cherubics use a homophone writing, with a musical discourse enclosed mostly in a binary meter - more rarely in the ternary meter (3/4 and even 6/8) - accompanied by minute agogic and expression indications. The initial tempo of the Classical-Romantic cherubic, usually bears the indication Adagio, with the specification ma non tropo, espressivo, sostenuto or Andante religioso, etc, and That we may receive the King of all - Allegro (moderato) etc. An agogic characteristic of these cherubics is constituted by the tempo changes operated throughout the musical discourse. The cherubics of Isidor Vorobchievici, Eduard Wachmann and Alexandru Flechtenmacher contain elements of the melodramatic musical language, specific to stage music: canto melody, wailing, in minor tonality; the trio of equal female voices, as a contrasting element; the polyphonic dialogue of the soloists, with a dramatic musical discourse; the use of accords interrupted by a break; of tone changes and tone schemes etc.

Eusebiu Mandicevschi approaches a Romantic language similar to the Brahmsian one, through the density of the harmonic canvas, with altered accords and crowded by melodic notes. Composer Gheorghe Dima wrote a Cherubic in the form of a motet, by the imitative succession of several phrases (Liturgy for a mixed choir), in the la minor tonality. That we may receive the King of all derives from the melodic motif of the Cherubic, presented, however, in the major homonym motion.

\section{Cherubics with capitalize the Byzantine church singing}

The choral capitalization of old Byzantine church songs began to concern Romanian composer only after 1880 , either in the form of a melodic quote, or by the creation of songs in the style of ecclesiastic music. In most cases, composers capitalized church songs belonging to Byzantine modes $\mathrm{V}$ and VIII. Chronologically, the versions of the Cherubic in mode VIII were the first ones used in the choral approach, in the liturgies of composers George Ionescu, Dumitru-Georgescu Kiriac, Ion Popescu-Pasărea, Gheorghe Cucu şi, ulterior, Ioan D. Chirescu, Nicolae Lungu, Ion Runcu, Grigore Panţâru s.a. The Cherubic in minor mode $\mathrm{V}$ was chorally capitalized by Teodor Teodorescu, Ioan $\mathrm{D}$. Chirescu and Nicolae Lungu. Both songs are quoted from collections of church 
songs according to Anton Pann. The composers combined the homophone writing and used a tone-modal sonorous framework. Usually, the song is entrusted to the soprano. The use of the harmonic pedal on the mode tonic and fifth refers to the accompaniment in the religious practice. The choral approach of these Byzantine songs is characterised by: unison passages combined with harmonic passages created by the motion in parallel third notes, short passages of imitative polyphony, fugato imitation, the melismatic, ornamented motion of melodies, the passage of the quoted song from one voice to another.

It distinguishes itself through the fact that in the choral approach of these songs composers Dumitru Georgescu-Kiriac and Ioan D. Chirescu often call on the polyphone writing, while Nicolae Lungu adopts a predominantly homophone writing. If the first ones quote church songs as faithfully as possible, from the religious books of precentor Ioan Popescu Pasărea, Nicolae Lungu intervenes on the oversized musical phrases, which he adjusts, bringing them to reasonable proportions.

\section{References}

1. Alexandrescu, D., (1998) Ghidul dirijorului de cor bisericesc, Editura Sfầntul Gheorghe-Vechi, Bucureşti

2. Barbu, Bucur, S., (1989) Cultura muzicală de tradiţie bizantină pe teritoriul României în secolul XVIII şi începutul secolului XIX şi aportul original al culturii autohtone, Editura Muzicală, Bucureşti

3. Branişte, E. (1993) Liturgica generală, Editura Institutului Biblic şi de Misiune al Bisericii Ortodoxe Române, Bucureşti

4. Branişte, E. (1980) Liturgica specială, Editura Institutului Biblic şi de Misiune al Bisericii Ortodoxe Române, București

5. Branişte, E. (1993) Liturgica specială, Editura Institutului Biblic şi de Misiune al Bisericii Ortodoxe Române, Bucureşti 